\title{
Vitality evaluation methods for newborn puppies after cesarean section performed under general inhalation anesthesia $^{1}$
}

\author{
Valéria N.L.S. Oliva ${ }^{2 *}$, Maria Carolina V.G. Queiroz ${ }^{3}$, Verônica B. Albuquerque ${ }^{4}$, \\ Janaína T. Carreira ${ }^{5}$, Talita F.B. Souza ${ }^{3}$, Gabriel T.N.M. Ferreira ${ }^{6}$, Caio J.X. Abimussi ${ }^{7}$ \\ and Juliana P. Vides ${ }^{8}$
}

\begin{abstract}
Oliva V.N.L.S., Queiroz M.C.V.G., Albuquerque V.B., Carreira J.T., Souza T.F.B., Ferreira G.T.N.M., Abimussi C.J.X. \&. Vides J.P. 2018. Vitality evaluation methods for newborn puppies after cesarean section performed under general inhalation anesthesia. Pesquisa Veterinária Brasileira 38(6):1172-1177. Departamento de Clínica, Cirurgia e Reprodução Animal, Faculdade de Medicina Veterinária de Araçatuba, Universidade Estadual Paulista, Rua Clovis Pestana 793, Araçatuba, SP 16050-680, Brazil. E-mail: voliva@fmva.unesp.br

This study aimed to demonstrate and to correlate possible methods for neonatal assessment in dogs born by elective cesarean surgery using inhalation anesthesia, enhancing its advantages and disadvantages as well as proposing lactate measurement as an adjunctive method of evaluation. After elective cesarean surgery of four bitches subjected to morphine premedication followed by propofol induction and sevoflurane anesthesia, 30 neonates were evaluated through blood sampling from the umbilical cord for lactate measurement and blood gas analyses, as well as neurological and cardiorespiratory assessment at birth and at 10 minutes of age. The neonates presented respiratory acidosis and acidemia at birth related to blood lactate values $(4.98 \pm 1.39 \mathrm{mmol} / \mathrm{L})$. Neurological and cardiorespiratory depressions were present at birth with recovery at 10 minutes and no complications were observed during the first 30 days of life. The methods for neonatal assessment used in this study are safe when appropriately interpreted and the effects of general anesthesia on neonates were transient. Blood lactate obtained from the umbilical cord can be an option for the evaluation of these patients.
\end{abstract}

INDEX TERMS: Dogs, newborn puppies, cesarean, inhalation, anesthesia, obstetrics, hypoxia, Apgar, sevoflurane, lactate, surgery.

\footnotetext{
${ }^{1}$ Received on March 27, 2017.

Accepted for publication on May 15, 2017.

${ }^{2}$ Faculdade de Medicina Veterinária de Araçatuba (FMVA), Universidade Estadual Paulista (Unesp), Rua Clovis Pestana 793, Araçatuba, SP 16050-680, Brazil. *Corresponding author: voliva@fmva.unesp.br

${ }^{3}$ Faculdade de Medicina Veterinária de Jaguariúna, Rodovia Dr. Adhemar Pereira de Barros, Jaguariúna, Campinas, SP 13086-501, Brazil.

${ }^{4}$ Research Worker Fundect/CNPq, Fellow level C, Universidade Federal do Mato Grosso do Sul (UFMS), Av. Senador Felinto Muller 2443, Campo Grande, MS 79070-900, Brazil.

${ }^{5}$ Centro Universitário de Rio Preto, Av. Clóvis Oger 900, São José do Rio Preto, SP 15035-580, Brazil.

${ }^{6}$ Autonomous Veterinarian, Rua São Luiz 244, São José do Rio Preto, SP 15014-470.

${ }^{7}$ Faculdades Integradas de Ourinhos, Centro Universitário Católico, BR-153 Km 339, Ourinhos, SP 19909-100, Brazil.

${ }^{8}$ Faculdade Católica Salesiano Auxilium, Rodovia Teotônio Vilela 3821, Araçatuba, SP 32285-040.
}

RESUMO.- [Métodos de avaliação da vitalidade neonatal de cães após cesariana sob anestesia geral inalatória.] Objetivou-se demonstrar e correlacionar os possíveis métodos de avaliação neonatal de filhotes de cães nascidos de cesarianas eletivas com a utilização de anestesia inalatória, apontando suas vantagens e desvantagens e propor a dosagem de lactato sanguíneo como prática auxiliar. Após a cesariana eletiva em quatro cadelas submetidas ao protocolo anestésico composto de morfina, propofol e sevofluorano, foram avaliados 30 neonatos com exames de sangue do cordão umbilical para dosagem de lactato e gases sanguíneos, avaliação neurológica e cardiorrespiratória realizadas no nascimento e aos 10 minutos de vida. Os animais apresentaram acidose respiratória com acidemia ao nascimento, associados a altos valores de lactato sanguíneo $(4,89 \pm 1,39 \mathrm{mmol} / \mathrm{L})$. Ocorreu depressão neurológica e cardiorrespiratória no nascimento, com recuperação após 10 minutos, sem complicações nos primeiros 30 dias. Pode-se 
concluir que os métodos de avaliação neonatal utilizados são seguros quando interpretados adequadamente e os efeitos da anestesia nos neonatos foram transitórios. 0 lactato do sangue umbilical pode ser opção na avaliação desses pacientes.

TERMOS DE INDEXAÇÃO: Cães, neonatal, cesariana, anestesia geral, inalação, obstetrícia, hipóxia, Apgar, sevoflurano, lactato, cirurgia.

\section{INTRODUCTION}

The techniques for cesarean surgery in bitches are the object of study of many authors who are interested in determining their effects on both the mother and the fetus (Lavor et al. 2004, Gabas et al. 2006), giving that anesthetic protocols are aimed at survival of both (Domingos et al. 2008).

All of the anesthetics available for veterinary practice are able to cross the placental barrier, quickly affecting the fetuses from the start of the surgical procedure to their removal, and therefore anesthesia can exert great influence on neonatal vitality (Gabas et al. 2006). The most frequently occurring consequence is neurological and/or cardiorespiratory depression, which can result in hypoxemia and higher mortality (Crissiuma et al. 2006, Veronesi et al. 2009).

The most commonly used methods for assessing neonatal vitality after cesarean surgery are the vital signs or the Apgar and neurological scales, which comprise relatively subjective criteria that should be used with caution, especially at the point of transition from fetal to neonatal life (Crissiuma et al. 2006, Lucio et al. 2009, Groppetti et al. 2010).

The Apgar index was developed by Virginia Apgar as a method for ascribing a score to the clinical status of infants at the first minute of life (Apgar 1953, Apgar et al. 1958). Ever since, this method has been used worldwide for neonatal assessment and decision making regarding ventilatory intervention in these patients (Veronesi et al. 2009). The credibility of the Apgar method in identifying asphyxia during birth is widely discussed because even though a few studies validated the low values as predictors of neurological disorders and mortality (Weinberger et al. 2000, Groppetti et al. 2010), others demonstrated a lack of correlation between the low results and complications, suggesting that there are limitations to its use (Marrin \& Paes 1988, Doebeli et al. 2013).

In neonatology nowadays, blood lactate measurement has been successfully used as an indicator of neonatal distress and is considered to be a reliable parameter of tissue perfusion, since its production arises from anaerobic glycolysis at the cytosol and increases in its values are seen during partial or total oxygen deprivation (Pang \& Boysen 2007). Blood lactate has been widely used for prognostic assessment and evaluation of treatment responses in critical patients (Nguyen et al. 2004). In infants born by dystocic labor or emergency cesarean section, high blood lactate values were correlated with death and neurological disorders (Groenendaal et al. 2003). The higher values obtained from blood samples of the umbilical cord are strongly related to asphyxia during birth (Silva et al. 2000).

Considering the aforementioned factors, adequate neonatal assessment is of major importance in determining the influence of anesthesia on and the clinical prognosis of neonates. The methods available for this assessment continue to lack scientific basis and clinical precision, seeing that the research in veterinary neonatology is still scarce. Therefore, the objectives of this study are to demonstrate and correlate possible methods of neonatal assessment in puppies born by elective cesarean surgery performed under sevoflurane anesthesia, as well as their advantages and disadvantages. I addition, new methods are proposed for investigating anesthesia in these cases.

\section{MATERIALS AND METHODS}

The study has been approved by the local Ethics Committee of Animal Usage, protocol no. 2008-000245. For this study, four healthy Labrador retriever bitches weighing 20 to $30 \mathrm{~kg}$ were accompanied during their first gestation after natural breeding. The four mothers accounted for a total of 30 neonates.

The estrous cycle of the bitches was accompanied based on serial examinations (every 48 hours) of vaginal cytology after the initial bleeding and vulvar edema, which characterize the proestrous. When the cellularity corresponding to the estrous was confirmed, the subjects were allowed to naturally breed with healthy Labrador retriever dogs. Pregnancy was confirmed through ultrasound examination of fetal vesicles at the 20th day following breeding. At 45 days of gestation a new ultrasound exam was performed together with radiographic imaging for an approximate count of the number of fetuses.

Starting at the 56th day of gestation, ultrasound examinations were performed daily together with temperature measurement in order to time the cesarean surgery. When rectal temperature was below $37.5^{\circ} \mathrm{C}$ or decreased by $1^{\circ} \mathrm{C}$, parturition was considered within the next 24 hours. During this period, new examinations were performed until fetal heart rate was found to be below 200 beats minute $^{-1}$ and signs of intestinal peristalsis, full bladder and stomach, reduction of amniotic fluid and movement were identified, indicating fetal maturity (Luvoni \& Grioni 2000). Surgeries were performed as soon as the mothers presented an increase in rectal temperature following the decrease, indicating the proximity of parturition (Domingos et al. 2008).

Immediately before pre anesthetic preparation of the mothers, $5 \mathrm{~mL}$ of blood was obtained from the cephalic vein for progesterone dosage. Premedication followed blood sampling and comprised intramuscular morphine chloride at $0.3 \mathrm{mg} \mathrm{kg}^{-1}$ (Dimorf; Cristália, Itapira-SP, Brazil). A 20-gauge catheter (Angiocath; BD, Juiz de Fora/MG, Brazil) was aseptically inserted in the cephalic vein for fluid administration (Ringer solution; Medical Line; São Paulo/SP, Brazil).

A 15-minute period was awaited before induction of general anesthesia, which comprised an intravenous bolus of propofol (Propovan; Cristália, Itapira/SP, Brazil) at $10 \mathrm{mg} \mathrm{kg}^{-1}$, followed by tracheal intubation and maintenance with sevoflurane (Sevorane; Abbott, São Paulo/SP, Brazil). Inhalation anesthesia was delivered by a calibrated vaporizer at $100 \%$ oxygen at 1 to $1.5 \mathrm{~L}$ minute ${ }^{-1}$ through a circle system (Takaoka; KTK, São Paulo/SP, Brazil) and concentrations were maintained between 2.5 and 3.5V\% according to each individual's anesthetic requirements for surgical anesthesia. Mothers were monitored during anesthesia for cardiovascular parameters (Cardiocap 5; Datex Ohmeda, Louisville/KY, USA).

Following uterine incision, the fetuses were removed one by one together with the adjacent placenta. Once fetal adnexa and fluids were cleansed off the fetuses, a $0.1 \mathrm{~mL}$ blood sample was obtained from the umbilical cord prior to its ligation, and subsequent blood samples were obtained from the jugular vein at 10 minutes, 4 and 30 days of life. Blood lactate, $\mathrm{pH}, \mathrm{PCO}_{2}, \mathrm{PO}_{2}, \mathrm{HCO}_{3}{ }^{-}$, hemoglobin and packed cell volume were measured in each blood sample. Blood analyses were performed immediately after sampling using portable analyzers 
both for lactate levels (Accutrend lactate; Roche, São Paulo/SP, Brazil) and blood gas analysis (i-Stat; Abbott, São Paulo/SP, Brazil).

Immediately after the first blood analysis, neonates were assessed for cardiorespiratory variables and the modified Apgar score (Apgar 1953) as well as neurologic reflexes (Feitosa \& Ciarlini 2001) (Table 1).

Evaluations were performed at the first and tenth minute of life.

In order to assess the response to pain stimulation, the digital fold was pressed and when withdrawal of the limb and crying followed, the response was considered positive. The suckling reflex was investigated by introducing the little finger in the mouth and verifying the response. The anogenital reflex was considered positive when stimulation of the genitalia and anus with a gauze covered finger was followed by voiding or defecation. The Magnus reflex was performed through lateral flexion of the neck in dorsal recumbency and the response was obtained with extension of the ipsilateral and flexion of the contra lateral limbs. The flexor reflex was assessed together with the pain stimulation by observing limb flexion (Feitosa \& Ciarlini 2001).

The mothers were kept warm using warming blankets and postoperative analgesia followed using an epidural injection of morphine at $0.1 \mathrm{mg} \mathrm{kg}^{-1}$ in the lumbosacral space. Puppies were allowed to remain with their mother immediately after their recovery from general anesthesia.

During the subsequent 30 days, all puppies were evaluated for behavioral and clinical parameters in order to detect any complications caused by the anesthetic procedure.

Statistical analyses were performed with ANOVA for repeated measures followed by Dunnet test for blood variables and McNemar test for neurologic reflexes. Significance was considered when $\mathrm{p}<0.05$.

\section{RESULTS}

Cesarean surgeries were performed at $59 \pm 1.5$ days of gestations and the mean progesterone level 12 hours before surgical intervention was $3.5 \pm 0.82 \mathrm{ng} \mathrm{mL}^{-1}$.

The total number of neonates was 30 and the mortality rate at or after birth was not statistically significant (Table 2).

The results of blood gas analyses performed on venous blood samples from the umbilical cord are presented in Table 3.

Blood lactate levels at 4 and 30 days were significantly lower compared to the levels at birth and at 10 minutes of life (Table 4).

The sum of the Apgar scores differed between the two time points (Table 5).

All neonates presented significant lower neurologic reflexes at the first minute of life compared to the tenth minute (Table 6).

\section{DISCUSSION}

There were no detectable neurological complications at the first 30 days of life in any of the Labrador retriever puppies evaluated in this study. The timing of the cesarean surgery as well as progesterone levels demonstrate that the surgical procedure was not premature, which guaranteed adequate fetal maturity and reliability of these results.

These factors are owed to the hormonal status of the mother during gestation. Following fecundation, progesterone is maintained at high levels by the corpus luteum and can reach up to $90 \mathrm{ng} \mathrm{mL}^{-1}$. Two days before birth an abrupt decrease is observed in its levels, reaching a minimum of $1 \mathrm{ng} \mathrm{mL}^{-1}$ at parturition (Benetti et al. 2004). This reduction happens because of the luteolithic action of the prostaglandin secreted by the placenta after stimulation by fetal cortisol secretion (Concannon et al. 2001).

The decision making for performing cesarean surgery was based on rectal temperature measurements starting at the 56 th day after breeding together with clinical and behavioral evaluation of the mother (reduced appetite, vomiting, reclusion, discharge of mucus) and ultrasound examination of the fetuses (slower cardiac rate, intestinal peristalsis, full bladder and stomach, reduction of amniotic fluid and movement) (Luvoni \& Grioni 2000).

The anesthetic procedures were accompanied by continuous monitoring of the mothers and there were no perioperative or postoperative complications. All mothers recovered from anesthesia quickly and uneventfully. Puppies were allowed to be with their mothers after complete recovery and were accepted without further problems. The absence of labor distress and the safety of the anesthetic procedure allowed for puppies to be delivered without complication, which was certainly a major factor for the low mortality and stillbirth rates of this study. One puppy died at the third day and this was attributed to the mother's relative inability of caring for it.

Blood gas analyses performed on venous blood samples from the umbilical cord (Table 3) showed high $\mathrm{PCO}_{2}$ values coupled with low $\mathrm{pH}$, which suggests a scenario of respiratory acidosis and severe acidemia at birth. These results corroborate other findings of low $\mathrm{pH}$ and high $\mathrm{PCO}_{2}$ of puppies born by cesarean surgery in three studies (Crissiuma et al. 2006, Gabas et al. 2006, Lucio et al. 2009). This scenario is also commonly observed during natural labor, as demonstrated by one study using umbilical cord blood samples (Vivan et al. $2009)$ that found high $\mathrm{PCO}_{2}$ values $(65 \pm 32 \mathrm{mmHg})$ and low $\mathrm{pH}$ (7.1 \pm 0.2$)$. Carbon dioxide accumulation on blood is an important factor for inducing a respiratory reflex in the neonate (Lucio et al. 2009).

Table 1. Modified Apgar scale for dog neonate assessment used in the first and tenth minute of life

\begin{tabular}{|c|c|c|c|}
\hline \multirow{2}{*}{ Parameter } & \multicolumn{3}{|c|}{ Score } \\
\hline & 0 & 1 & 2 \\
\hline Heart beat & Absent & Slow $\left(<100\right.$ beats minute $\left.{ }^{-1}\right)$ & Fast $\left(>100\right.$ beats minute $\left.^{-1}\right)$ \\
\hline Respiratory effort & Absent & Slow, irregular, mild crying & Good, regular, vigorous crying \\
\hline Muscle tone & Flaccid & Some flexions & Active motion \\
\hline Reflex irritability & Absent & Facial expression, facial movement & Coughing, sneezing \\
\hline Skin color & Pale & Cyanotic & Pink \\
\hline
\end{tabular}

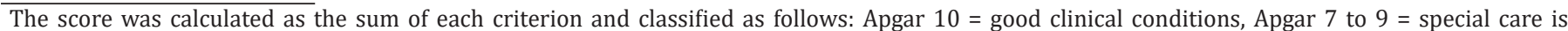
unnecessary, Apgar 3 to 6 = requires oxygen therapy, Apgar 0 to 2 = severe anoxia, requires reanimation maneuvers (Lavor et al. 2004). 
Table 2. Mortality rate at and after birth in puppies born by cesarean surgery under inhalation anesthesia

\begin{tabular}{cccc}
\hline Condition & $\mathrm{N}$ & $\%$ & $\mathrm{p}^{(*)}$ \\
\hline Alive & 29 & 97,5 & \\
Stillborn & 0 & 0 & 0,022 \\
Mortality & 1 & 2,5 & \\
Total & 30 & 100 & \\
* Fisher exact test. & & &
\end{tabular}

Table 3. Mean values of $\mathrm{pH}, \mathrm{PCO}_{2}, \mathrm{PO}_{2}$ and $\mathrm{HCO}_{3}$ of venous blood samples obtained from the umbilical cord of puppies born by cesarean surgery under inhalation anesthesia

\begin{tabular}{cc}
\hline Parameter & Mean \pm standard deviation \\
\hline $\mathrm{pH}$ & $7.108 \pm 0.08$ \\
$\mathrm{PCO}_{2}$ & $69.84 \pm 12.2 \mathrm{mmHg}$ \\
$\mathrm{PO}_{2}$ & $15.76 \pm 6.03 \mathrm{mmHg}$ \\
$\mathrm{HCO}_{3}$ & $21.72 \pm 3.38 \mathrm{mmol} \mathrm{L}^{-1}$
\end{tabular}

Table 4. Mean \pm standard deviation of blood lactate values ( $\mathrm{mmol} \mathrm{L} \mathrm{L}^{-1}$ ) at different time points of puppies born by cesarean surgery under inhalation anesthesia

\begin{tabular}{cc}
\hline Time point & Lactate $(x \pm S)$ \\
\hline Birth & $4.76 \pm 1.48^{\mathrm{a}}$ \\
10 minutes & $5.25 \pm 2.36^{\mathrm{a}}$ \\
4 days & $2.38 \pm 1.24^{\mathrm{b}}$ \\
30 days & $2.23 \pm 1.10^{\mathrm{b}}$
\end{tabular}

Means followed by the same letter do not differ according to Tukey test $(\mathrm{p}>0.05)$.

Table 5. Mean \pm standard deviation of the modified Apgar score of puppies born by cesarean surgery under inhalation anesthesia in the first and tenth minute of life

\begin{tabular}{cc}
\hline Time point (minutes) & Apgar $(x \pm S)$ \\
\hline 1 & $2.47 \pm 1.33^{\mathrm{b}}$ \\
10 & $9.23 \pm 2.13^{\mathrm{a}}$
\end{tabular}

Means followed by the same letter do not differ according to Tukey test $(\mathrm{p}>0.05)$.

Blood gas alterations in the subjects of this study were likely caused by respiratory depression that persisted until removal of the placenta, which was evidenced by the Apgar score. With placental removal at birth, neonatal asphyxia immediately follows, inducing the inspiratory effort and assuring the initial respiratory movement (Lucio et al. 2009). Neonatal respiratory depression is aggravated by general anesthesia during cesarean surgery owing to the effects of the anesthetics together with the recumbent position of the mother, which causes a decrease in arterial blood pressure and uterine blood flow. These effects indirectly affect fetal viability by decreasing transplacental oxygen transfer in conjunction with the direct depression of the fetuses by the anesthetics (Gabas et al. 2006, Lucio et al. 2009).

In one study performed on dog neonates born by natural labor, oxytocin-induced labor or cesarean surgery, high levels of mixed acidosis were seen regardless of the conception method,
Table 6. Number of puppies according to the presence or absence of neurologic reflexes in the first and tenth minute of life

\begin{tabular}{ccccc}
\hline Reflex & & 1st minute & 10th minute & $\mathrm{p}^{*}$ \\
\hline Pain & Absent & 21 & 2 & $<0.0001$ \\
& Present & 9 & 28 & \\
\multirow{3}{*}{ Flexor } & Total & 30 & 30 & \\
& Absent & 21 & 2 & $<0.0001$ \\
& Present & 9 & 28 & \\
Suckling & Total & 30 & 30 & \\
& Absent & 28 & 2 & $<0.0001$ \\
& Present & 2 & 28 & \\
& Total & 30 & 30 & \\
& Absent & 30 & 2 & $<0.0001$ \\
& Present & 0 & 28 & \\
Magnus & Total & 30 & 30 & \\
& Absent & 29 & 2 & $<0.0001$ \\
& Present & 1 & 28 & \\
& Total & 30 & 30 & \\
& & & &
\end{tabular}

$\bar{*}$ McNemar test.

and changed to a metabolic alkalosis in the oxytocin group at 60 minutes after birth. In that study, the authors concluded that adverse conditions can result in severe alterations of blood gas variables (Lucio et al. 2009). In addition, a few studies in dogs demonstrated the usefulness of $\mathrm{pH}$ assessment together with other parameters such as clinical evaluation, $\mathrm{PCO}_{2}$ and bicarbonate for establishing the clinical prognosis of the neonate after birth (Crissiuma et al. 2006, Lucio et al. 2009).

Blood lactate obtained from the umbilical cord presented high values $\left(4.89 \pm 1.39 \mathrm{mmol} \mathrm{L}^{-1}\right)$ compared to normal references for adult dogs, which vary between 1.1 and $2.5 \mathrm{mmol} \mathrm{L}^{-1}$ (McMichael et al. 2005, Pang \& Boysen 2007, Bueno et al. 2012). These findings can be interpreted as expected results, seeing that the neonate requires elevated energy substrates for metabolism, especially in the brain, due to its insufficient glycogen reserves and low tolerance to hypoglycemia (McMichael et al. 2005).

It should be additionally considered that the physiological stress caused by anesthesia and the upcoming parturition, especially concerning respiratory depression, can contribute to the reduced supply of oxygen to the tissues (Lucio et al. 2009, Bueno et al. 2012). At the time of birth, mean blood lactate from the umbilical cord was $4.89 \pm 1.39 \mathrm{mmol} \mathrm{L}^{-1}$ and remained close to $4.86 \pm 1.35 \mathrm{mmol} \mathrm{L}^{-1} \mathrm{t} 10$ minutes of life in the blood drawn from the jugular vein. Umbilical blood lactate in this study was lower compared to a similar investigation by the authors on neonates born by natural labor. In the previous study, 25 subjects were evaluated and mean blood lactate was $6.26 \pm 2.7 \mathrm{mmol} \mathrm{L}^{-1}$ (Vivan etal. 2009). The different findings can indicate a better condition of cesarean-delivered compared to naturally delivered puppies, since labor can at times persist for hours and cause fetal depression. It is necessary, however, to weigh the effects of the anesthetics on fetuses against these differences since many studies refer anesthesia as a cause of changes in blood lactate metabolism, which in turn result in decreased lactate values (Willigers et al. 2003, Floriano et al. 2010). 
Blood lactate was not decreased over time in these puppies, which is an expected finding seeing that the values coincide with the clinical and neurological progress following support therapy of these patients. This can be explained by the short period of time awaited between these evaluations (which might not have been sufficient to evidence the clearance of blood lactate, or the washout period) (Leavy et al. 1988). This phenomenon occurs after the reestablishment of proper blood circulation and comprises the mobilization of lactate produced during hypoxia from peripheral tissues to the global circulation, increasing or maintaining systemic levels despite a visible improvement in the clinical scenario.

The inclusion of blood lactate in the clinical practice of neonatology is recent. In foals, the high correlation between blood lactate and death has been demonstrated in previous studies (Henderson et al. 2008, Castagnetti et al. 2010).

In dogs, lactate measurement is recently being used for intensive care (Lagutshik et al. 1998, Papp et al. 1999), however only a few studies have been published in neonatology. In 2009, a group of researchers referred mean values of $6.3 \pm 2.7 \mathrm{mmol} \mathrm{L}^{-1}$ in blood samples from the umbilical cord of puppies born by natural labor, and a strong correlation was found between higher values and complications or death. Puppies with blood lactate above $8 \mathrm{mmol} \mathrm{L}^{-1}$ either died or presented neurological complications that suggested previous hypoxemia (Vivan et al. 2009).

In this study, blood lactate values were measured at 4 and 30 days of life from blood samples of the jugular vein and mean values of $2.53 \pm 1.35 \mathrm{mmol} \mathrm{L}^{-1}$ and $1.93 \pm 0.93 \mathrm{mmol} \mathrm{L}^{-1}$, respectively, were observed. These findings were significantly lower compared to the levels at birth and are similar to the results of naturally delivered puppies $(2.37 \pm 0.99$ and 2.57 $\pm 1.09 \mathrm{mmol} \mathrm{L}^{-1}$ ) (Vivan et al. 2009) but different from another study that found higher levels at $4(3.83 \pm 1.38 \mathrm{mmol}$ $\left.\mathrm{L}^{-1}\right)$ and $28\left(2.70 \pm 0.95 \mathrm{mmol} \mathrm{L}^{-1}\right)$ days compared to 80 days of life (McMichael et al. 2005).

The different results can be ascribed to the familiarity of the team with the mothers and the rapid blood sampling without excessive restraint. Stress is a major factor for elevated blood lactate levels owing to adrenalin release, which accelerates glycolysis and exceeds the oxidative capability of the mitochondria (Bueno et al. 2012).

No correlation was found between blood lactate and $\mathrm{pH}$, $\mathrm{PCO}_{2}, \mathrm{PO}_{2}$, bicarbonate levels or Apgar score at birth. Significant correlation was found solely between blood lactate and Apgar score at 10 minutes of life. These findings differ from other studies performed in 2009 where a strong correlation was seen between $\mathrm{pH}$ or $\mathrm{PCO}_{2}$ and blood lactate levels from the umbilical cord in puppies delivered through natural labor (Vivan et al. 2009). The correlation is expected in this case, considering that the main effect of general anesthesia on the fetuses is respiratory depression, which was demonstrated in the present study by respiratory acidosis and acidemia. This depression is known to impair tissue oxygenation and cause higher lactate levels in infants (Groenendaal et al. 2003).

The means of Apgar score at different time points were $2.3 \pm 1.27$ at 1 minute after birth and $9.0 \pm 2.4$ at 10 minutes, and the results were significantly different. This demonstrates that animals were born with notable depression and recovered to a better clinical status within the first 10 minutes of life after receiving routine neonatal care, such as cleaning of the airway passage.

Previous studies used the Apgar index for neonatal assessment in subjects born by natural labor or cesarean surgery, being the lower values related to the cesarean group and likely caused by apnea during the first minutes after birth (Gabas et al. 2006). Similar findings were described when different anesthetic methods were used and lower Apgar scores were seen at birth, increasing within the first 10 minutes of life (Lavor et al. 2004). In this study, the lower Apgar values at birth might be ascribed to respiratory depression and the effects of general anesthesia on the subjects.

Similar results were observed on neurological parameters, since the tested reflexes were statistically lower at birth compared to the tenth minute of life, as demonstrated in Table 6. Other authors have found similar results in these parameters, being most subjects in those studies born by cesarean surgery without normal responses to the Magnus, suckling and anogenital reflexes at birth and progressive improvement to normal responses at 10 minutes (Gabas et al. 2006). Those results are in agreement with this study with regard to the hypothesis that the clinical and neurological depression seen in these puppies was owed to the anesthetic procedure without subsequent clinical complications. The Apgar and the neurological evaluation are easy to perform and do not require specific devices, however there is some subjectivity and examiner influence on the results, which warrants its association with quantitative methods of neonatal assessment (Lucio et al. 2009, Veronesi et al. 2009, Doebeli et al. 2013).

\section{CONCLUSIONS}

The neonates in this study presented respiratory and neurological depression at birth associated with high blood lactate levels, although lower than other studies using naturally delivered subjects. All animals presented a significant clinical and neurological improvement at 10 minutes, which can indicate that depression was mainly caused by the effects of general anesthesia and does not represent an ongoing situation of clinical significance.

The evaluations demonstrated in this study provide appropriate methods for neonatal assessment, and their limitations should be previously known in order to properly interpret the results. The acid-base analysis is a safe method for identifying acidosis in these patients; however the higher cost might pose a difficulty in the clinical scenario. Blood lactate can be a viable option for this matter, given that it provides objective information concerning the clinical condition and prognosis of the patients together with lower cost and the smaller blood sample required for its measurement. However, the influence of anesthesia on lactate levels is to be determined and considered for its use in clinical practice.

Conflict of interest statement.- The authors have no competing interests.

Acknowledgements.- The authors would like to thank CAPES for the scholarship, FAPESP for the financial support to this study and Professor Silvia Helena Venturolli Perri for all the statistical analyses.

\section{REFERENCES}

Apgar V. 1953. A proposal for a new method of evaluation of the newborn infant. Curr. Res. Anesth. Analg. 32(4):260-267. PMid:13083014. 
Apgar V., Holaday D.A., James L.S., Weisbrot I.M. \& Berrien C. 1958. Evaluation of the newborn infant: second report. J. Am. Med. Assoc. 168(15):1985-1988. http://dx.doi.org/10.1001/jama.1958.03000150027007. PMid:13598635.

Benetti A.H., Toniollo G.H. \& Oliveira J.A. 2004. Concentrações séricas de progesterona, 17 ß-estradiol e cortisol durante o final do proestro, estro e diestro gestacional em cadelas. Ciência Rural 34(2):471-478. http:// dx.doi.org/10.1590/S0103-84782004000200021.

Bueno L.M.C., Lopes M.D., Lourenço M.L.G., Prestes N.C., Takahira R.K., Derussi A.A.P. \& Sudano M.J. 2012. Concentração de lactato e glicemia em cadelas e neonatos nascidos de cesariana. Arq. Bras. Med. Vet. Zootec. 64(6):14421448. http://dx.doi.org/10.1590/S0102-09352012000600006.

Castagnetti C., Pirrone A., Mariella J. \& Mari G. 2010. Venous blood lactate evaluation in equine neonatal intensive care. Theriogenology 73(3):343-357. http://dx.doi.org/10.1016/j.theriogenology.2009.09.018. PMid:19962183.

Concannon P., Tsutsui T. \& Shille V. 2001. Embryo development, hormonal requirements and maternal responses during canine pregnancy. J. Reprod. Fertil. 57(suppl. ):169-179. PMid:11787146.

Crissiuma A.L., Labarthe N.V., Juppa C.J., Mannarino R., Soares A.M.B. \& Gershony L.C. 2006. Analyzing blood gasometry at 3 time points of the fetal-neonatal transitional period of dogs born by elective caesarean section parturition. Intern. J. Appl. Res. Vet. 4:15-22.

Doebeli A., Michel E., Bettschart R., Hartnack S. \& Reichler I.M. 2013. Apgar score after induction of anesthesia for canine cesarean section with alfaxalone versus propofol. Theriogenology 80(8):850-854. http://dx.doi. org/10.1016/j.theriogenology.2013.07.006. PMid:23932170.

Domingos T.C., Rocha A.A. \& Cunha I.C. 2008. Cuidados básicos com a gestante e o neonato canino: revisão de literatura. J. Bras. Ciênc. Anim. 1:94-120.

Feitosa M.M. \& Ciarlini L.D. 2001. Exame neurológico de cães neonatos. Cães Gatos 15:20-26.

Floriano B.P., Oliveira G.C., Vivan M.C. \& Oliva V.N.L.S. 2010. Lactato sanguíneo na avaliação dos efeitos da peridural torácica em cães anestesiados pelo isofluorano. Ciência Rural 40(3):574-579. http://dx.doi.org/10.1590/ S0103-84782010005000023.

Gabas D.T., Matsubara L.M., Oliva V.N.L.S., Rodello L., Rossi C.N. \& Perri S.H.V. 2006. Estado neurológico e cardiorrespiratório de filhotes de cães nascidos de parto normal ou de cesariana sob anestesia geral inalatória com sevofluorano. Ciência Rural 36(5):1450-1455. http://dx.doi.org/10.1590/ S0103-84782006000500016.

Groenendaal F., Lindemans C., Uiterwaal C.S.P.M. \& de Vries L.S. 2003. Early arterial lactate and prediction of outcome in preterm neonates admitted to a neonatal intensive care unit. Biol. Neonate 83(3):171-176. http:// dx.doi.org/10.1159/000068927. PMid:12660433.

Groppetti D., Pecile A., Del Carro A.P., Copley K., Minero M. \& Cremonesi F. 2010. Evaluation of newborn canine viability by means of umbilical vein lactate measurement, Apgar score and uterine tocodynamometry. Theriogenology 74(7):1187-1196. http://dx.doi.org/10.1016/j.theriogenology.2010.05.020. PMid:20615542.

Henderson I.S.F., Franklin R.P., Wilkins P.A. \& Boston R.C. 2008. Boston CR. Association of hiperlactatemia with age, diagnosis, and survival in equine neonates. J. Vet. Emerg. Crit. Care 18(5):496-502. http://dx.doi. org/10.1111/j.1476-4431.2008.00349.x.

Lagutshik M.S., Ogilvie G.K., Hackett K.B. \& Wingfield W.E. 1998. Increased lactate concentrations in ill and injured dogs. Vet. Emerg. Crit. Care 8:127-137.
Lavor M.S.L., Pompermayer L.G., Nishiyama S.M., Duarte T.S., Filgueiras R.R. \& Odenthal M.E. 2004. Efeitos fetais e maternos do propofol, etomidato, tiopental e anestesia epidural, em cesarianas eletivas de cadelas. Ciência Rural 34(6):1833-1839. http://dx.doi.org/10.1590/S0103-84782004000600026

Leavy J.A., Weil M.H. \& Rackow E.C. 1988. "Lactate washout" following circulatory arrest. JAMA 260(5):662-664. http://dx.doi.org/10.1001/ jama.1988.03410050082034. PMid:3392792.

Lúcio C.F., Silva L.C.G., Rodrigues J.Á., Veiga G.A.L. \& Vannucchi C.I. 2009. AcidBase changes in canine neonates following normal birth or dystocia. Reprod. Domest. Anim. 44(Suppl. 2):208-210. http://dx.doi.org/10.1111/j.14390531.2009.01428.x. PMid:19754570.

Luvoni G.C. \& Grioni A. 2000. Determination of gestational age in medium and small size bitchies using ultrasonographic fetal measurements. J. Small. Anim. Pract. 41(7):292-294. http://dx.doi.org/10.1111/j.1748-5827.2000 tb03204.x. PMid:10976623.

Marrin M. \& Paes B.A. 1988. Birth asphyxia: does the apgar score have diagnostic value? Obstet. Gynecol. 72(1):120-123. PMid:3288927.

McMichael M.A., Lees G.E., Hennessey J., Sanders M. \& Boggess M. 2005. Serial plasma lactate concentrations in 68 puppies aged 4 to 80 days. J. Vet. Emerg. Crit. Care 15(1):17-21. http://dx.doi.org/10.1111/j.15346935.2005.04026.x.

Nguyen B., Rivers E.P., Knoblich B.P., Jacobsen G., Muzzin A., Ressler J.A. \& Tomlanovich M.C. 2004. Early lactate clearance is associated with improved outcome in severe sepsis and septic shock. Crit. Care Med. 32(8):1637-1642. http://dx.doi.org/10.1097/01.CCM.0000132904.35713.A7. PMid:15286537.

Pang D.S. \& Boysen S. 2007. Lactate in veterinary critical care: pathophysiology and management. J. Am. Anim. Hosp. Assoc. 43(5):270-279. http://dx.doi. org/10.5326/0430270. PMid:17823476.

Papp E., Drobatz K.J. \& Hughes D. 1999. Plasma lactate concentration as a predictor of gastric necrosis and survival among dogs with gastric dilatationvolvulus: 102 cases (1995-1998). J. Am. Vet. Med. Assoc. 215(1):49-52. PMid:10397065.

Silva S., Hennebert N., Denis R. \& Wayenberg J.L. 2000. Clinical value of a single postnatal lactate measurement after intrapartum asphyxia. Acta Paediatrica 89(3):320-323. http://dx.doi.org/10.1111/j.1651-2227.2000. tb01334.x. PMid:10772280.

Veronesi M.C., Panzani S., Faustini M. \& Rota A. 2009. An Apgar scoring system for routine assessment of newborn puppy viability and short-term survival prognosis. Theriogenology 72(3):401-407. http://dx.doi.org/10.1016/j. theriogenology.2009.03.010. PMid:19476989.

Vivan M.C.R., Vides J.P., Souza T.F.B., Albuquerque V.B. \& Oliva V.N.L.S. 2009. Umbilical cord blood lactate in the assessment of fetal stress during delivery in dogs. World Congress of Veterinary Anaesthesia, Glasgow, UK, p.137.

Weinberger B., Anwar M., Hegyi T., Hiatt M., Koons A. \& Paneth N. 2000 Antecedents and neonatal consequences of low apgar scores in preterm newborns. Arch. Paediatr. Adolesc. Med. 154(3):294-300. http://dx.doi. org/10.1001/archpedi.154.3.294. PMid:10710031.

Willigers H.M., Prinzen F.W., Roekaerts P.M., de Lange S. \& Durieux M.E. 2003 Dexmedetomidine decreases perioperative myocardial lactate release in dogs. Anesth. Analg. 96(3):657-664. http://dx.doi.org/10.1213/01. ANE.0000048708.75957.FF. PMid:12598239. 